DOI: $10.20472 / I A C .2018 .044 .055$

\author{
ZINAIDA ZAKHARANKA \\ Belarusian State University of Transport, Belarus
}

\title{
FEATURES OF TEACHING ECONOMIC DISCIPLINES FOR STUDENTS OF ARCHITECTURAL AND CONSTRUCTION SPECIALTIES IN THE REPUBLIC OF BELARUS
}

\begin{abstract}
:
In the article features of teaching of economic disciplines for students of architectural and building specialties in higher educational institutions of the Republic of Belarus are presented on an example of calculation of the total estimated cost of construction products. It should be noted that the formation of prices in construction is one of the important stages in the preparation of design estimates, therefore the development of a unified approach to the calculation of cost, taking into account the dynamics of its development is fundamental in the process of teaching economic disciplines.

It is important to take into account that in the current conditions of intensive implementation of various software complexes for the calculation of building structures, in particular based on BIM-technologies, the corresponding programs for the preparation of budget documentation are also widely used. In this situation, at the teaching stage it is important to form the understanding of the principles of drawing up the estimate documentation for the learner, because a correct assessment of the adequacy of the resulting "automated" solutions is the key in determining the competence of any specialist.

Important in teaching the course "Construction economics" has a close relationship of the principles of formation of the value of construction products with the basics of technology and the organization of construction. In this connection, when presenting theoretical material on the "Construction economics", information about the technology and organization of construction production should be largely provided. It should be noted that the teaching of special economic disciplines takes place at the final courses of study, i.e. after completing the relevant specialized courses "Technology of construction" and "Organization of construction", which allows you to freely consider those or other features of the construction process in the aspect of economic evaluation. In general, the main purpose of accounting for the principles of construction production in the teaching of economic disciplines is the correct definition of labor, machinery and material resources, taking into account the selected production technology. At the same time, it is important to note that the study of the basics of calculating the cost of construction products in conjunction with the technology of production of works allows the future specialist to exclude errors in the selection of norms and quotations as much as possible, to reduce the amount of information entered and, as a result, to improve the quality of the estimated budget and resource documentation.
\end{abstract}

\section{Keywords:}

Construction-assembling works, Project and technology module, Estimated cost, Local estimate, Direct costs, Object estimate, Summary estimated cost

JEL Classification: A12, L74 


\section{Introduction}

At the present time, the main direction of the development of the construction industry of different countries is the solution of problems associated with the long-term socioeconomic policies of each of the states, taking into account effective functioning in the world market.

Among the basic principles of such development, we can single out the acceleration of economic growth, the creation of competitive industries, the construction of new industrial and civil buildings and structures.

The importance of studying the discipline "Construction economics" is to acquire skills in determining the economic efficiency of investment in construction, identifying the characteristics of market relations, analyzing the production and economic activities of the construction organization, and the formation of a material and technical base and studying the main directions of the economy and rational use of raw minerals, energy and other resources.

For students of architectural and construction specialties in the Republic of Belarus, the discipline "Construction economics" refers to the cycle of general professional and special disciplines. The main purpose of its study is to form students understanding of the construction economy, in particular, the principles of the formation of value for construction products, methods of economic work in market conditions and their use in practice [1].

It is important to note that the introduction of BIM-technology in the calculation of the price of construction products helps students quickly get a set of resource and budget documentation. In such conditions of maximum automation of the process of preparation of design and estimate documentation, the main evaluation criterion for the qualification of any specialist is a competent analysis of the solutions obtained, as well as an understanding of the principles of regulating the resource intensity of the construction process over time under possible changing conditions. In this regard, it is obvious that at the stage of training a specialist it is necessary to provide information on the individual stages of the formation of the final cost of products, maximally working out each of them. It is this approach that allows the student to form a full understanding of the method of determining the value of construction products.

A special feature of teaching the discipline "Construction economics" is its relationship with the special disciplines "Technology of construction" and "Organization of construction". In this connection, when presenting theoretical material on the "Construction economics", information about the technology and organization of construction production should be largely provided.

The currently existing principles for calculating the estimated value of construction products have a long history of development, which began in 1811-1812 years (the 
first document on standardization in construction was developed). In the 50-60 years last century with the development of technology and the improvement of the organization of construction production, a basic form of economic evaluation of designed and erected buildings and structures was developed, which included the following stages:

- drawing up of the statement of quantities of work;

- formation of design and technological modules;

- determination of the composition and calculation of resources;

- determination of the estimated cost of construction according to elemental estimates and enlarged indicators.

In the 90 years in the process of formation of the sovereign system of the economy of the construction sector, resource and base-index methods were developed to calculate the cost of construction. In the future, in connection with the gradual introduction of the global settlement system, the construction economy also began to transform. Currently, the basis for calculating the estimated cost of construction is based on the principles of determining the cost of the resource method based on resource consumption rates (specifications of the expense of resources in natural expression SER in NE-2017) at current prices using forecasted price indices that take into account the change in prices from the date of the beginning of the development of the estimate documentation until the completion of the standard construction period, allows you to determine the most accurate cost of erecting an object for a specific period of time.

Let's consider the basic principles of the modern approach to determine the estimated cost of construction products in accordance with the current norms Republic of Belarus and the relationship of the construction economics with technology and construction organization.

\section{Drawing up a statement of quantities}

The first stage of calculating the estimated cost of construction involves determining directly the volume of construction-assembling works.

At performance of the given stage the sheet of calculation of volumes of works which consists of the list of consistently executed works and formulas of their calculation is formed. The volume counting list covers all structural elements and types of work. The amount of work and materials from the project elements are collected according to the estimated rules. Units of measurement of structures or works must accurately correspond to the units of measurement adopted in the norms $\left(\mathrm{m}^{2}, \mathrm{~m}^{3}, 100 \mathrm{~m}^{2}, 100\right.$ 
$\mathrm{m}^{3}$, tons and pieces). To facilitate and simplify the work on the compilation of volumes it is recommended:

- counting by constructive elements and types of work should be carried out in such a manner that the results of previously performed calculations could be used for subsequent ones. For example, the first calculation of the amount of work to fill the apertures provides, in the future, data for the deduction of openings from the area of walls, partitions and surfaces to be trimmed;

- for typical and repetitive structural elements and parts of buildings, it is advisable to have pre-compiled auxiliary tables with the necessary data;

- use the specifications in projects as much as possible.

In accordance with the above, calculations of the scope of work on sections are recommended to be conducted in the following order:

1. General construction works: openings in external walls, openings in internal walls and partitions, walls, foundations, excavations, partitions, floors, ceilings, roof, stairs, balconies, peaks, interior finishing, exterior finishing, other work.

2. Internal sanitary facilities and special works: water supply, sewerage, heating, ventilation, hot water supply, gas supply, electricity, other works.

In the list of workload calculations, each separately taken work or constructive element is drawn up as an independent line. Statements of scope of work are presented in the Tables 1-3.

\section{Table 1 - Statement of earth-moving works}

\begin{tabular}{|c|c|c|c|}
\hline $\begin{array}{c}\text { Name of work item and element } \\
\text { of construction }\end{array}$ & $\begin{array}{c}\text { Unit of } \\
\text { measure- } \\
\text { ment }\end{array}$ & Formula for calculating & $\begin{array}{l}\text { Scope } \\
\text { of } \\
\text { work }\end{array}$ \\
\hline Pitting by bulldozer & $1000 \mathrm{~m}^{3}$ & $\begin{array}{c}(12+12+5+5) \cdot(60+5+ \\
\quad+5) \cdot 0,25=595 \mathrm{~m}^{3}\end{array}$ & 0,595 \\
\hline $\begin{array}{l}\text { Area planning by mechanized } \\
\text { means }\end{array}$ & $1000 \mathrm{~m}^{2}$ & $\begin{array}{c}(12+12+5+5) \cdot(60+5+ \\
+5)=2380 \mathrm{~m}^{2}\end{array}$ & 2,380 \\
\hline $\begin{array}{l}\text { Soil excavation and backhoe } \\
\text { attachment with dipper capacity } \\
\text { of } 0,5 \mathrm{~m}^{3}\end{array}$ & $1000 \mathrm{~m}^{3}$ & $\begin{array}{c}\mathrm{V}=1 / 6 \cdot 1,5 \cdot((2 \cdot 2+3) \times \\
\times 62+(2 \cdot 3+2) \cdot 63)= \\
234,5 \approx 235 \mathrm{~m}^{3}\end{array}$ & 0,235 \\
\hline $\begin{array}{l}\text { Hand excavation in a 2-metre- } \\
\text { deep trench without fastening } \\
\text { and with slopes (3\%) }\end{array}$ & $100 \mathrm{~m}^{3}$ & $0,03 \cdot 235=7,05 \approx 7 \mathrm{~m}^{3}$ & 0,07 \\
\hline $\begin{array}{l}\text { Dirt-moving for backfilling to the } \\
\text { reserve at a distance of } 40 \mathrm{~m}\end{array}$ & $1000 \mathrm{~m}^{3}$ & $235+7=242 \mathrm{~m}^{3}$ & 0,242 \\
\hline
\end{tabular}


Table 2 - Statement of backfilling ground works

\begin{tabular}{|l|c|c|c|}
\hline $\begin{array}{c}\text { Name of work item and element } \\
\text { of construction }\end{array}$ & $\begin{array}{c}\text { Unit of } \\
\text { measure- } \\
\text { ment }\end{array}$ & Formula for calculating & $\begin{array}{c}\text { Scope } \\
\text { of } \\
\text { work }\end{array}$ \\
\hline $\begin{array}{l}\text { Dirt-moving for backfilling to the } \\
\text { reserve at a distance of } 40 \mathrm{~m} \\
\text { and refilling of trench }\end{array}$ & $1000 \mathrm{~m}^{3}$ & $\begin{array}{c}(1,5 \cdot 1,5 \cdot 0,6+0,9 \cdot 0,9 \times \\
\times 0,9) \cdot 33=68,61 \approx 69 \mathrm{~m}^{3} \\
242-69=173 \mathrm{~m}^{3}\end{array}$ & 0,173 \\
\hline $\begin{array}{l}\text { Earth compacting of an } \\
\text { underneath foundation of } \\
\text { industrial workshops }\end{array}$ & $100 \mathrm{~m}^{2}$ & $\begin{array}{c}(12+12+1+1) \cdot(60+ \\
+1+1)=1612 \mathrm{~m}^{2}\end{array}$ & 16,12 \\
\hline
\end{tabular}

Table 3-Statement of foundations works

\begin{tabular}{|l|c|c|c|}
\hline $\begin{array}{c}\text { Name of work item and element } \\
\text { of construction }\end{array}$ & $\begin{array}{c}\text { Unit of } \\
\text { measure- } \\
\text { ment }\end{array}$ & Formula for calculating & $\begin{array}{c}\text { Scope } \\
\text { of } \\
\text { work }\end{array}$ \\
\hline $\begin{array}{l}\text { The device of concrete } \\
\text { preparation from concrete of a } \\
\text { class C8/10 }\end{array}$ & $100 \mathrm{~m}^{3}$ & $(2 \cdot 2 \cdot 0,2) \cdot 33=26,4 \mathrm{~m}^{3}$ & 0,264 \\
\hline $\begin{array}{l}\text { General-purpose rock-solid } \\
\text { foundation that made from } \\
\text { concrete of C12/15class by the } \\
\text { volume of up to } 3 \mathrm{~m}^{3}\end{array}$ & $100 \mathrm{~m}^{3}$ & $\begin{array}{c}(1,5 \cdot 1,5 \cdot 0,6+0,9 \cdot 0,9 \times \\
\times 0,9) \cdot 33=68,61 \mathrm{~m}^{3}\end{array}$ & 0,686 \\
\hline
\end{tabular}

\section{Formation of design and technological modules}

The transformation of design data into the structure of the estimate in the software package on the basis of BIM-models is carried out according to the designtechnological modules. The cost of construction-assembling works is calculated on project and technology modules [2]. Project and technological module - a complex of construction-assembling works, technologically connected to each other and oriented in accordance with the project documentation for the execution of uniform types and types of work. The order of grouping the data by project and technological module must comply with the technological sequence of work and consider the specific characteristics of certain types of construction.

The cost group coding system and project and technology modules of objects the republican data bank has the following structure: 


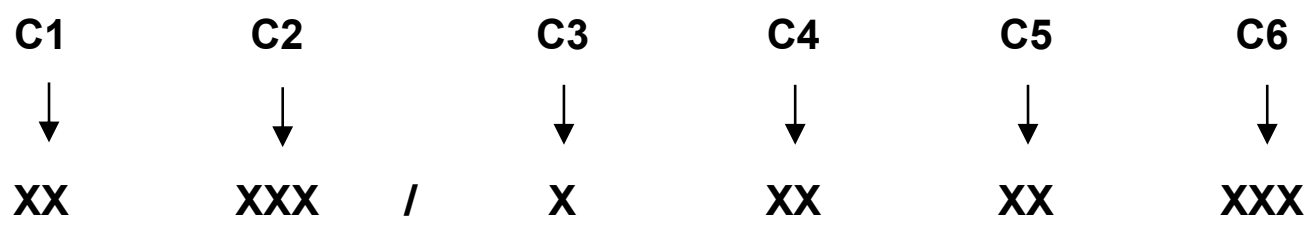

$\mathrm{C} 1$ - chapter of summary estimated cost;

C2 - object estimate's number;

C3 - 1st level of expenses;

C4 - 2nd level of expenses;

C5 - 3rd level of expenses;

C6 - additional characteristics of the type of work.

Cost structure, a system of coding cost groups and project and technological module are presented in the Table 4.

Table 4 - Cost structure, a system of coding cost groups and project and technological module

\begin{tabular}{|c|c|c|c|c|c|c|}
\hline \multicolumn{4}{|c|}{ Cost level code } & \multirow[b]{2}{*}{ Name of cost groups } & \multicolumn{2}{|c|}{ Settlement indicator } \\
\hline$\frac{\bar{\Phi}}{\stackrel{\Xi}{\sigma}}$ & $\frac{\bar{d}}{N}$ & $\frac{\bar{d}}{m}$ & 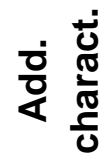 & & $\begin{array}{c}\text { Unit of } \\
\text { mea- } \\
\text { surement }\end{array}$ & Name \\
\hline \multirow[t]{5}{*}{1} & 00 & 00 & & $\begin{array}{c}\text { PREPARATION OF THE } \\
\text { TERRITORY }\end{array}$ & \multirow{4}{*}{$m^{2}$} & \multirow{4}{*}{$\begin{array}{l}\text { Area of the site } \\
\text { allocated for } \\
\text { construction }\end{array}$} \\
\hline & 10 & 00 & & Land allotment & & \\
\hline & 20 & 00 & & $\begin{array}{l}\text { Obtaining initial data } \\
\text { (technical specifications) }\end{array}$ & & \\
\hline & 30 & 00 & & Compensatory payments & & \\
\hline & 40 & 00 & & Other costs & & Under the project \\
\hline \multirow[t]{5}{*}{2} & 00 & 00 & & $\begin{array}{c}\text { BUILDING - } \\
\text { CONSTRUCTION PART }\end{array}$ & $m^{2}$ & $\begin{array}{c}\text { In accordance with } \\
\text { normative } \\
\text { documentation }\end{array}$ \\
\hline & 10 & 00 & & Earth-moving works & $\mathrm{m}^{3}$ & $\begin{array}{c}\text { The volume of earth- } \\
\text { moving works }\end{array}$ \\
\hline & 10 & 10 & & Foundation pit & & \\
\hline & 20 & 10 & & $\begin{array}{l}\text { Foundations-building } \\
\text { constructs }\end{array}$ & $\mathrm{m}^{3}$ & Foundation volume \\
\hline & 20 & 10 & 010 & Monolithic & $\mathrm{m}^{3}$ & Foundation volume \\
\hline
\end{tabular}


In this way:

PTM for earth-moving works - 0200121010

PTM for backfilling ground works - 0200121030

PTM for foundations - 0200122010010

\section{Determination of resources (using the example of a concrete preparation device)}

When calculating resources, it is necessary to distinguish the norms used in construction. Norms can be estimated - they assume that the work is carried out according to the "average technology", so do not take into account the additional consumption of materials associated with the production of work in winter (fuel and other materials), cover the natural loss of construction materials, the cost of work performed for account of overhead expenses (manufacturing scaffolds and others); cannot serve as a basis for writing off materials at cost; and production - taking into account the production features. Production standards are developed in accordance with the guidelines for the technical standardization of the consumption of materials in construction, based on the requirements for the production of works provided for by construction norms and rules. The full technically justified rate of consumption of building materials is:

$$
H_{p r}=H_{c}+H_{w}+H_{l}
$$

where: $\boldsymbol{H}_{\boldsymbol{c}}$ - constructive, pure rate of consumption of materials, that is, the amount of materials needed to produce a unit of production without taking into account waste, losses arising at all stages of storage, movement within the construction site and piling into the case;

$\boldsymbol{H}_{\boldsymbol{w}}, \boldsymbol{H}_{\boldsymbol{l}}$ - accordingly admissible waste and losses of materials which take place in the period of preparation for the production process and also at the movement of materials within the construction site and laying them in business (for example, cuttings, shavings, sawdust of wood obtained during the manufacture of joinery products, loss of bulk materials, small waste when laying molded products, reinforcing steel when reinforcing monolithic reinforced concrete structures).

In accordance with the technology of production of works, we determine the necessary resources for the device of concrete preparation. Resources for concrete preparation are presented in the Table 5. 
Table 5 - Resources for concrete preparation $\left(100 \mathrm{~m}^{3}\right)$

\begin{tabular}{|c|c|c|c|}
\hline $\begin{array}{l}\text { Resource } \\
\text { code }\end{array}$ & $\begin{array}{c}\text { Name of works, resources, } \\
\text { expenses }\end{array}$ & Units & Consumption rate \\
\hline & $\begin{array}{l}\text { Average category of } \\
\text { construction workers }\end{array}$ & & 3,1 \\
\hline $1-1$ & $\begin{array}{l}\text { Labor costs of construction } \\
\text { workers }\end{array}$ & person-hours & 160,65 \\
\hline \multirow[t]{2}{*}{$1-3$} & Labor costs of machinists & person-hours & 10 \\
\hline & Machines and mechanisms & & \\
\hline M021141 & Cranes on the road $10 t$ & machine-hours & 8,7 \\
\hline M110102 & Tubs with a capacity of $4 \mathrm{~m}^{3}$ & machine-hours & 8,03 \\
\hline M110907 & Vibrators & machine-hours & 8,03 \\
\hline \multirow[t]{2}{*}{ M331617 } & $\begin{array}{l}\text { Means of small-scale } \\
\text { mechanization }\end{array}$ & machine-hours & 1,3 \\
\hline & $\begin{array}{c}\text { Materials, products, } \\
\text { structures }\end{array}$ & & \\
\hline C412-9005 & Water & $\mathrm{m}^{3}$ & 1,75 \\
\hline C414-1001 & $\begin{array}{l}\text { Concrete is heavy with the size } \\
\text { of aggregate } 20-40 \mathrm{~mm} \text {, class } \\
\text { C8/10 }\end{array}$ & $\mathrm{m}^{3}$ & 102 \\
\hline
\end{tabular}

\section{Composing of a local estimate}

Local estimates are the primary estimate document. They are compiled on the basis of physical volumes of work, structural drawings of the elements of buildings and structures, accepted methods of production and, as a rule, are grouped individually according to project and technological module (PTM). The order of the grouping of the data oaccording to PTM should correspond to the technological sequence of work and consider the specific features of certain types of construction. The cost, determined by local cost estimates, includes direct costs $(\boldsymbol{D C})$, overhead $(\boldsymbol{O})$ costs notional profit $(\boldsymbol{P})$ :

$$
C=D C+O+P
$$

Direct costs include the payment for the labour of building tradesmen, the costs of operating construction machines and mechanisms, the cost of materials, parts and structures, transportation costs.

Labour costs that refered to the payment for the labour of an employee are refered directly to construction work, as well as workers who move materials from the working area and warehouse to the site of installation. Table 6 shows the calculation of the workers' salary based on the number of labor contribution, the skill category and the price of person/hour of the 4th skill category of construction workers. 
The labor costs of workers are refered to the management and maintenance of construction machinery are included in the cost of operating these machines, which are determined on the basis of the number of machine/hours and the cost of one machine/hour. In those articles, labour costs of secondary proceedings are not considered.

The cost of materials includes the costs of purchasing, semi-products, products, items and structures required for the production of construction-assembling works. The estimated cost of materials, products and structures is accepted according to the current price level at the date of the composing of the estimate documentation.

Table 6- Calculation of workers' salary

\begin{tabular}{|c|c|c|c|c|c|}
\hline \multirow{2}{*}{ Types of work } & $\begin{array}{c}\text { Unit of } \\
\text { measure- } \\
\text { ment }\end{array}$ & $\begin{array}{l}\text { Labor costs } \\
\text { person/hour }\end{array}$ & $\begin{array}{l}\text { Labour input, } \\
\text { person/hour }\end{array}$ & $\begin{array}{c}\text { The skill category } \\
\text { of construction } \\
\text { workers }\end{array}$ & \multirow{2}{*}{$\begin{array}{l}\text { Salary, } \\
\text { BYN }\end{array}$} \\
\hline & Quantity & $\begin{array}{l}\text { Coefficient to } \\
\text { the labor } \\
\text { costs }\end{array}$ & $\begin{array}{l}\text { Coefficient to } \\
\text { the labor } \\
\text { costs }\end{array}$ & Grade coefficient & \\
\hline \multirow{2}{*}{$\begin{array}{l}\text { The device of } \\
\text { concrete } \\
\text { preparation from } \\
\text { concrete of a } \\
\text { class } C 8 / 10\end{array}$} & $100 \mathrm{~m}^{3}$ & 160,65 & 3,1 & 4,75 & \multirow[b]{2}{*}{666,39} \\
\hline & 0,264 & 1 & 0,8739 & 1 & \\
\hline
\end{tabular}

Transportation costs, including procuring and storage expenses, for the delivery of general construction materials from the manufacturers to the warehouse of the construction object are determined depending on the cost of materials for three zones of construction projects in the following amounts, \%:

- in urban areas - 8,9;

- in rural areas - 13.4;

- in Minsk - 8.6.

Overhead are provided for in construction estimates to own expenses of the construction organization related to the organization and management of construction, providing the necessary production and economic conditions for the functioning of the construction process, organization and maintenance of construction-assembling works. They're trying to become part of the cost of construction-assembling works. 
The notional profit is deductions of money resources for a covering of expenses of the building organization on development of manufacture and material stimulation of workers (the notional profit does not concern to the cost price of works).

Overhead and notional profit are accrued in accordance with the established norms of the wages of workers and machinists while determining the estimated cost of construction, installation and repair work, general economic.

Local estimate shows in Table 7.

Table 7 - Local estimate for foundations concluded on prices for July 2018

\begin{tabular}{|c|c|c|c|c|c|c|c|c|c|}
\hline & \multirow{3}{*}{ Report } & \multirow{3}{*}{$\begin{array}{c}\text { Name of types of } \\
\text { activity }\end{array}$} & \multirow{3}{*}{$\begin{array}{c}\begin{array}{c}\text { Unit of } \\
\text { measure } \\
\text { ment }\end{array} \\
\text { Amount }\end{array}$} & \multicolumn{6}{|c|}{ Unit cost / total, BYN } \\
\hline \multirow[t]{2}{*}{ 운 } & & & & \multirow{2}{*}{$\begin{array}{c}\text { Salary } \\
\text { of } \\
\text { labour } \\
\text { of } \\
\text { constr } \\
\text { uction } \\
\text { worker } \\
s\end{array}$} & \multicolumn{2}{|c|}{\begin{tabular}{|c|} 
Operation \\
of \\
machinery \\
and \\
mechanism \\
s \\
\end{tabular}} & \multirow{2}{*}{\begin{tabular}{|c|} 
Material \\
s, \\
product \\
s, \\
structur \\
es \\
(equipm \\
ent \\
furnitur \\
e, \\
inventor \\
y)
\end{tabular}} & \multirow{2}{*}{ Transp } & \multirow{2}{*}{$\begin{array}{l}\text { Tota } \\
I \\
\text { cost }\end{array}$} \\
\hline & & & & & Tota & $\begin{array}{l}\text { Includ } \\
\text { ing } \\
\text { salary } \\
\text { of } \\
\text { mashi } \\
\text {-nists }\end{array}$ & & & \\
\hline \multirow[t]{2}{*}{1} & 2 & 3 & 4 & 5 & 6 & 7 & 8 & 9 & 10 \\
\hline & $\begin{array}{c}\text { PTM } \\
02001 \\
220 \\
10010\end{array}$ & $\begin{array}{c}\text { Foundations: } \\
\text { overhead / notional } \\
\text { profit (58,78 \% / 64,84 } \\
\%)\end{array}$ & & & & & & & \\
\hline \multirow[t]{4}{*}{1} & \multirow[t]{2}{*}{ E6-1-1 } & \multirow{2}{*}{$\begin{array}{l}\text { The device of concrete } \\
\text { preparation from } \\
\text { concrete of a class } \\
\text { C8/10 }\end{array}$} & $100 \mathrm{~m}^{3}$ & $\begin{array}{c}666,3 \\
9\end{array}$ & $\begin{array}{c}111,4 \\
2\end{array}$ & 28,07 & $\begin{array}{c}5 \\
260,84\end{array}$ & $\begin{array}{c}468,0 \\
6\end{array}$ & $\begin{array}{c}6 \\
506,7 \\
2\end{array}$ \\
\hline & & & 0,264 & $\begin{array}{c}175,9 \\
3\end{array}$ & 29,42 & 7,41 & $\begin{array}{c}1388,8 \\
6\end{array}$ & $\begin{array}{c}123,5 \\
7\end{array}$ & $\begin{array}{c}1717 \\
78\end{array}$ \\
\hline & \multirow{2}{*}{$1-1$} & \multirow{2}{*}{$\begin{array}{c}\text { Labour inputs } \\
\text { (the skill category- } \\
3,1)\end{array}$} & $\begin{array}{c}\text { person/ho } \\
\text { ur }\end{array}$ & 4,15 & & & & & \\
\hline & & & 160,65 & $\begin{array}{c}666,3 \\
9\end{array}$ & & & & & \\
\hline \multirow{2}{*}{\multicolumn{2}{|c|}{$\begin{array}{c}\mathrm{M} 02114 \\
1\end{array}$}} & \multirow{2}{*}{ Automobile crane $10 t$} & $\begin{array}{c}\text { machine/h } \\
\text { our }\end{array}$ & & 11,86 & 2,92 & & & \\
\hline & & & 8,7 & & $\begin{array}{c}103,1 \\
6 \\
\end{array}$ & 25,38 & & & \\
\hline \multirow{2}{*}{\multicolumn{2}{|c|}{$\begin{array}{c}M 11010 \\
2\end{array}$}} & \multirow{2}{*}{$\begin{array}{c}\text { Bucket with capacity of } \\
4 \mathrm{~m}^{3}\end{array}$} & $\begin{array}{c}\text { machine/h } \\
\text { our }\end{array}$ & & 0,14 & & & & \\
\hline & & & 8,03 & & 1,11 & & & & \\
\hline \multirow{2}{*}{\multicolumn{2}{|c|}{$\begin{array}{c}\text { M11090 } \\
7\end{array}$}} & \multirow[t]{2}{*}{ Vibrators } & $\begin{array}{c}\text { machine/h } \\
\text { our }\end{array}$ & & 0,21 & & & & \\
\hline & & & 8,03 & & 1,66 & & & & \\
\hline \multirow{2}{*}{\multicolumn{2}{|c|}{$\begin{array}{c}\text { M33161 } \\
7\end{array}$}} & \multirow[t]{2}{*}{ Labor saving tools } & $\begin{array}{c}\text { machine/h } \\
\text { our }\end{array}$ & & 4,23 & 2,07 & & & \\
\hline & & & 1,3 & & 5,50 & 2,69 & & & \\
\hline \multirow{2}{*}{\multicolumn{2}{|c|}{$\begin{array}{l}\text { C412- } \\
9005\end{array}$}} & \multirow[b]{2}{*}{ Water } & $\mathrm{m}^{3}$ & & & & 0,99 & & \\
\hline & & & 1,75 & & & & 1,72 & & \\
\hline
\end{tabular}




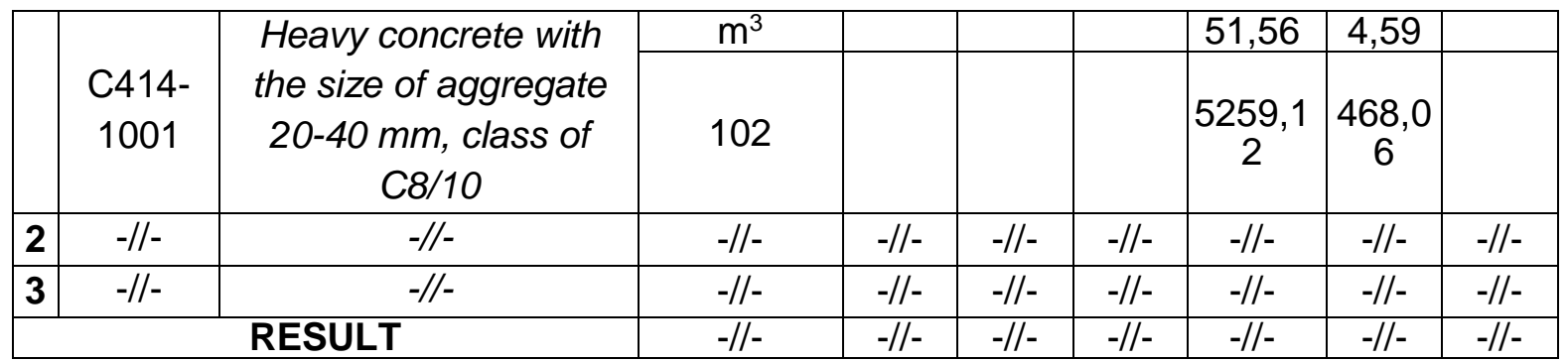

\section{Composing of the objected estimate}

The estimated cost of object includes the final values from the local estimates in terms of the kinds of activities. The objected estimate contains the cost indicators: salary of labour of construction workers; operation of machinery and mechanisms, including salary of machinists; materials, products; transport costs; overhead costs; notional profit; equipment, furniture and inventory; other means; total cost.

In g. 9 the normative labor costs of the work is showed. The complexity of work is defined as the sum of costs in person-hours, recorded in the standardizing costs of resources for construction-assembling works, and labor costs recorded by overhead costs, which are determined by formula:

$$
T_{0}=K \cdot O \text {, }
$$

where $\boldsymbol{K}$ - coefficient of transition from the amount of expenses of overhead costs (BYN) to labor costs (person-hour);

O- overhead costs (BYN).

Object estimate shows in Table 8. 


\section{Table 8 - Object estimate}

\begin{tabular}{|c|c|c|c|c|c|c|c|c|}
\hline \multirow{3}{*}{$\begin{array}{l}\text { Number } \\
s \text { of the } \\
\text { cost } \\
\text { estimate } \\
\text { s and } \\
\text { calculati } \\
\text { ons }\end{array}$} & \multirow{3}{*}{$\begin{array}{c}\text { Names of } \\
\text { work, } \\
\text { expenses }\end{array}$} & \multicolumn{6}{|c|}{ Cost, H.BYN } & \multirow[b]{2}{*}{$\begin{array}{l}\text { Total } \\
\text { cost, } \\
\text { H.BYN. }\end{array}$} \\
\hline & & \multirow{2}{*}{$\begin{array}{c}\text { Salary } \\
\text { of } \\
\text { labour } \\
\text { of } \\
\text { constru } \\
\text { ction } \\
\text { worker } \\
\text { s }\end{array}$} & \multirow{2}{*}{\begin{tabular}{|c}
$\begin{array}{c}\text { Machines } \\
\text { and } \\
\text { mechanis } \\
\text { ms }\end{array}$ \\
operations \\
$\begin{array}{c}\text { Salary of } \\
\text { machinist } \\
\text { s }\end{array}$
\end{tabular}} & \multirow{2}{*}{\begin{tabular}{|c|}
$\begin{array}{c}\text { Materials, } \\
\text { products, } \\
\text { designs }\end{array}$ \\
$\begin{array}{c}\text { Transpor } \\
\mathbf{t}\end{array}$ \\
\end{tabular}} & \multirow{2}{*}{$\begin{array}{c}\begin{array}{c}\text { Overhe } \\
\text { ad } \\
\text { costs }\end{array} \\
\begin{array}{c}\text { Notiona } \\
\text { I profit }\end{array}\end{array}$} & \multirow{2}{*}{\begin{tabular}{|c}
$\begin{array}{c}\text { Equipm } \\
\text { ent, } \\
\text { furnitur } \\
\text { e }\end{array}$ \\
$\begin{array}{c}\text { Transpo } \\
\text { rt }\end{array}$
\end{tabular}} & \multirow[t]{2}{*}{$\begin{array}{c}\text { Other } \\
\text { mean } \\
s\end{array}$} & \\
\hline & & & & & & & & $\begin{array}{c}\text { Labour } \\
\text { costs }\end{array}$ \\
\hline 1 & 2 & 3 & 4 & 5 & 6 & 7 & 8 & 9 \\
\hline & The amount & & 0,928 & 5,517 & 1,400 & & & 11,990 \\
\hline & $\begin{array}{l}\text { of general } \\
\text { construction } \\
\text { works }\end{array}$ & 2,115 & 0,268 & 0,491 & 1,545 & & & 670 \\
\hline Calcula & Central & 0063 & 0,028 & 0,166 & 0,042 & & & 0,359 \\
\hline & heating & 0,003 & 0,008 & 0,015 & 0,046 & & & 20 \\
\hline Calcula & Ventilation & 0063 & 0,028 & 0,166 & 0,042 & & & 0,359 \\
\hline tion & veminalion & 0,003 & 0,008 & 0,015 & 0,046 & & & 20 \\
\hline Calcula & Water cunnlv & 0127 & 0,056 & 0,331 & 0,084 & & & 0,719 \\
\hline tion & Vualer supply & $0,1<7$ & 0,016 & 0,029 & 0,093 & & & 40 \\
\hline Calcula & & O 042 & 0,019 & 0,110 & 0,028 & & & 0,239 \\
\hline tion & watersupply & 0,042 & 0,005 & 0,009 & 0,031 & & & 13 \\
\hline Calcula & Canalisation & 0,042 & 0,019 & 0,110 & 0,028 & & & 0,239 \\
\hline tion & vallalisaluom & $0,04<$ & 0,005 & 0,009 & 0,031 & & & 13 \\
\hline Calcula & Gas-s & $0,4 ?$ & 0,019 & 0,110 & 0,028 & & & 0,239 \\
\hline tion & Gas-supply & 0,042 & 0,005 & 0,009 & 0,031 & & & 13 \\
\hline & Electric & & 0,037 & 0,221 & 0,056 & & & 0,479 \\
\hline $\begin{array}{c}\text { Calcula } \\
\text { tion }\end{array}$ & $\begin{array}{c}\text { lighting and } \\
\text { electrical } \\
\text { facility }\end{array}$ & 0,085 & 0,011 & 0,019 & 0,062 & & & 27 \\
\hline & & 2580 & 1,132 & 6,731 & 1,708 & & & 14,634 \\
\hline & Uㄴㄴㄴ & 2,500 & 0,327 & 0,599 & 1,884 & & & 816 \\
\hline
\end{tabular}

\section{Composing of the summary estimated cost of objects construction}

The summary estimated cost - is the main document that determines the cost of construction. In the calculation, almost all costs for the construction of the object are reflected:

Chapter 1. Preparation of a built-up area.

Chapter 2. Major buildings, constructions.

Chapter 3. Buildings, constructions of ancillary and maintenance purposes. 
Chapter 4. Buildings, constructions of the energy economy.

Chapter 5 Buildings, transport facilities and communications.

Chapter 6. External supply lines and constructions of water supply, sewerage, heat supply and gas supply.

Chapter 7. Landscaping.

Chapter 8. Temporary buildings and erections.

Chapter 9. Other work and expenses.

Chapter 10. Customer's, developer's funds includes.

Chapter 11. Training of operational staff.

In the chapters of the consolidated estimate calculation, the estimated cost of individual objects and types of work, defined in the object (local) estimates, is presented in a separate line with the distribution according to graphs: "salary of labour of construction workers", "operation of machinery and mechanisms, including salary of machinists", "materials, products and structures", "transport costs", "overhead costs", "planned profit", "equipment, furniture and inventory", "other means", "total cost".

A separate graph is the normative labour costs.

The summary estimated cost provides the totals for each chapter and the totals for Chapters 1-7, 1-8, 1-9, 1-11.

The result of Chapters 1-11 is calculated reserve of funds for unforeseen work and costs, taxes and deductions in accordance with current legislation and funds that take into account the use of forecast price indices in construction.

For the total summary cost estimate, returnable amounts are indicated, taking into account the sale of materials and parts obtained from disassembly of temporary buildings and structures $-15 \%$ of the estimated cost of temporary buildings and construction, regardless of the period of construction (repair) of the facility.

\section{Methodical recommendations for the calculation of funds that take into account the use of predictive price indices in construction, taking into account the normative duration of construction}

For the purpose of reflecting in the estimate documentation the changes in the cost of the construction of the facility from the date of the beginning of the development of the estimate documentation until the completion of the standard construction period. 
Forecast price indices in construction are shown in Table 9.

Table 9 - A building cost price index on 2018

\begin{tabular}{|l|l|l|l|}
\hline Period & $\mathbf{2 0 1 8}$ & Period & $\mathbf{2 0 1 8}$ \\
\hline January & 1,0060 & July & 1,0060 \\
\hline February & 1,0060 & August & 1,0060 \\
\hline March & 1,0060 & September & 1,0060 \\
\hline April & 1,0060 & October & 1,0060 \\
\hline May & 1,0060 & November & 1,0060 \\
\hline June & 1,0060 & December & 1,0060 \\
\hline
\end{tabular}

The input for the calculation:

Date of composing of the estimate documentation (in prices)

July 1, 2018

Date set for beginning the construction

Normative construction period, months

Total for the summary estimate calculation, including taxes, BYN.

As of equipment

Customer costs that are not subject to indexation,

0,146

Funds for design and survey work, expertise

0,618

Total for the summary estimate for indexation, BYN.

33,131

Calculation of funds that take into account the use of forecast price indices in construction, according to the normative duration of construction, are carried out according to the form given in Table 10.

Table 10 - Calculation of predicted price building indices based on the duration of construction

\begin{tabular}{|l|c|c|c|c|}
\hline \multirow{2}{*}{ Name } & \multicolumn{4}{|c|}{ Month in which the work was performed } \\
\cline { 2 - 5 } & \multicolumn{3}{|c|}{2018} \\
\cline { 2 - 5 } & September & October & November & December \\
\hline $\begin{array}{l}\text { Standard of the construction } \\
\text { backlog, \% }\end{array}$ & 25,00 & 25,00 & 25,00 & 25,00 \\
\hline Cost, $r$. & 8,283 & 8,283 & 8,283 & 8,282 \\
\hline As of returnable sums & $-0,015$ & $-0,015$ & $-0,015$ & $-0,015$ \\
\hline $\begin{array}{l}\text { The rate applied to determine } \\
\text { means that take into account the } \\
\text { using of predicted index. }\end{array}$ & 1,0181 & 1,0242 & 1,0304 & 1,0365 \\
\hline $\begin{array}{l}\text { Means that take into account the } \\
\text { using of predicted price indices }\end{array}$ & 0,1499 & 0,2004 & 0,2518 & 0,3023 \\
\hline
\end{tabular}




\begin{tabular}{|l|l|l|l|l|}
\hline within scheduled time. & & & & \\
\hline As of returnable sums & $-0,0153$ & $-0,0154$ & $-0,0155$ & $-0,0156$ \\
\hline
\end{tabular}

Summary estimated cost shows in Table 11.

\section{Table 11 - Summary estimated cost}

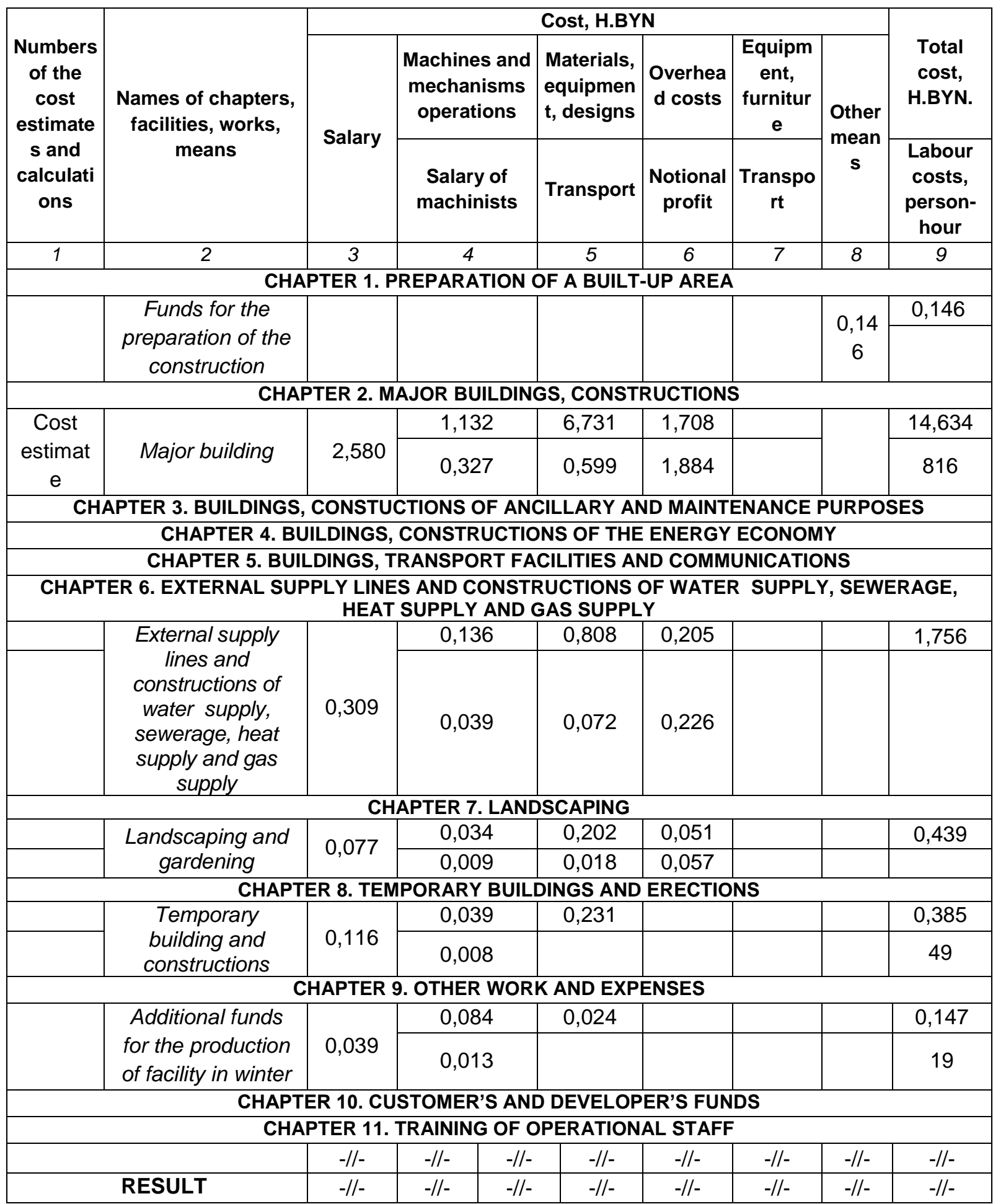




\section{Conclusion}

Determination of the estimated cost of construction is an important stage of the preparatory and design period for the construction of buildings and structures. In this regard, teaching the basics of this process is an integral part of the educational process of future architects, engineers, managers of the building complex, etc. The above stages of determining the estimated cost of construction include all the basic principles of practical implementation of this process in real conditions. It should be noted that the calculation of the cost of construction and preparation of estimate documentation students carry out in practical classes. Students consolidate and develop the following skills:

- use basic scientific and theoretical knowledge to solve practical problems;

- own system and comparative analysis;

- be able to work independently and have skills related to the use of technical devices, information management and work with the computer;

- competently apply the norms of resource consumption taking into account the technological features of construction;

- to form a consolidated estimate of the cost of construction, taking into account the specifics of the production of construction works;

- own the structure of value and cost;

- be able to compile reports in accordance with established forms;

- learn to work in a team.

The basic scientific and theoretical knowledge for successful fulfillment of practical tasks students receive in lecture classes. Calculation of resource and budget documentation is carried out in a software package based on BIM-models. After completing the assignment in practical classes, the student should explain the formation of the cost of construction products by elements and cost items. Tasks for practical work are developed individually for each student.

The result of studying the discipline "Construction economics" is the protection of course work and passing the exam.

Thus, we can draw the following conclusions about the methodology of teaching economic disciplines for students specializing in industrial and civil construction: 
- the effectiveness of teaching economic disciplines is determined by the chosen methodology in particular the system of interrelated lecture and practical classes;

- a feature of teaching the discipline "Construction economics" is its relationship with special subjects, such as technology and the organization of construction production.

\section{References}

OCBO 1-70 02 01-2013 "Industrial and civil construction". Educational standard. Republic of Belarus.

ТКП 45-1.02-302-2015 (33020) (DIN 277:2005) Building. Technical and economic indicators of the construction site. Rules for the determination of areas and volumes of buildings and structures. Minsk, 2015. Ministry of Architecture and Construction of the Republic of Belarus. 